\title{
A modified acidic approach for DNA extraction from plant species containing high levels of secondary metabolites
}

M.M. Cavallari ${ }^{1}$, M.V.B.M. Siqueira ${ }^{2}$, T.M. Val ${ }^{3}$, J.C. Pavanelli', M. Monteiro ${ }^{1}$, C. Grando ${ }^{4}$, J.B. Pinheiro ${ }^{3}$, M.I. Zucchi ${ }^{1}$ and M.A. Gimenes ${ }^{5}$

${ }^{1}$ Agência Paulista de Tecnologia dos Agronegócios, Polo Apta Centro-Sul, Piracicaba, SP, Brasil

${ }^{2}$ Central de Laboratórios de Pesquisa, Ciência e Tecnologia Ambiental, Pró-Reitoria de Pesquisa e Pós-Graduação, Universidade do Sagrado Coração, Bauru, SP, Brasil

${ }^{3}$ Laboratório de Diversidade Genética e Melhoramento, Departamento de Genética, Escola Superior de Agricultura Luiz de Queiroz, Universidade de São Paulo, Piracicaba, SP, Brasil ${ }^{4}$ Instituto de Biologia, Universidade Estadual de Campinas, Cidade Universitária Zeferino Vaz, Campinas, SP, Brasil

${ }^{5}$ Embrapa Recursos Genéticos e Biotecnologia, Parque Estação Biológica, Brasília, DF, Brasil

Corresponding author: M.V.B.M. Siqueira

E-mail: mvbsiqueira@gmail.com

Genet. Mol. Res. 13 (3): 6497-6502 (2014)

Received August 30, 2013

Accepted June 17, 2014

Published August 25, 2014

DOI http://dx.doi.org/10.4238/2014.August.25.13

ABSTRACT. Purified genomic DNA can be difficult to obtain from some plant species because of the presence of impurities such as polysaccharides, which are often co-extracted with DNA. In this study, we developed a fast, simple, and low-cost protocol for extracting DNA from plants containing high levels of secondary metabolites. This 
protocol does not require the use of volatile toxic reagents such as mercaptoethanol, chloroform, or phenol and allows the extraction of high-quality DNA from wild and cultivated tropical species.

Key words: DNA extraction; Secondary metabolites;

Tropical species; Casearia sylvestris; Cultivated crops

\section{INTRODUCTION}

The use of molecular markers often requires high-quality genomic DNA (Narayanan et al., 2006). Purified genomic DNA can be difficult to obtain from some plant species because of the presence of impurities such as terpenes, polyphenols, and polysaccharides, which are often co-extracted with DNA (Shepherd et al., 2002). Polyphenolic compounds are powerful oxidizing agents present in many plant species and can cause serious contamination problems during DNA extraction by binding to nucleic acids, preventing their use in most research applications (Li et al., 2002).

Our research team examines the population genetics of several tropical plant species; we often observe co-extraction of polyphenols and other secondary metabolites during DNA isolation. One such species presenting this challenge is Casearia sylvestris Sw. (Salicaceae), a neotropical tree used utilized in popular medicine and recent drug development efforts (Sertie et al., 2000). The DNA of C. sylvestris obtained using the CTAB extraction protocol (Doyle and Doyle, 1990) is invariably brown in color, and although degradation was not observed on agarose gels, PCR using specific microsatellite markers is frequently unsuccessful. A previous study on this species reported poor PCR amplification using RAPD markers because of the co-extraction of polyphenols during DNA isolation (Silva et al., 2006).

In addition to the CTAB method (Doyle and Doyle, 1990), other protocols (Aljanabi et al., 1999; Chaudhry et al., 1999) were tested on C. sylvestris for comparison. The Plant DNAzol Reagent DNA extraction kit (GibcoBRL, Life Technologies, Grand Island, NY, USA) was also tested. None of the methods yielded high-quality DNA.

Using information from previously tested protocols, we developed a new method based on the acidic protocol described by Csaikl et al. (1998), which is a scaled-up version of the original acidic DNA extraction protocol described by Ziegenhagen et al. (1993). Our protocol differs from previous methods mainly because of the addition of sodium bisulfite in the extraction buffer and because phenol, chloroform, and isoamyl alcohol are unnecessary.

\section{MATERIAL AND METHODS}

Casearia sylvestris samples were collected from 9 natural populations of São Paulo State, Brazil. Leaf samples were collected from the field and kept on silica gel until they were completely dehydrated. Accessions of Lippia alba were obtained from a germplasm collection at Departamento de Genética of Escola Superior de Agricultura Luiz de Queiroz of Universidade de São Paulo (ESALQ/USP). The remaining species were obtained from the campus of ESALQ/USP, Piracicaba, Brazil, or provided by our collaborators. Leaves were immediately stored at $-80^{\circ} \mathrm{C}$.

The protocol was also tested on other species for which DNA extraction is often difficult, including Anacardium humile (a wild relative of cashew; Anacardiaceae), L. alba (a 
south-American medicinal plant; Verbenaceae), Piptadenia gonoacantha (a tree used for restoration; Fabaceae-Mimosoideae), Vellozia squamata (a typical shrub from Cerrado; Velloziaceae), and Myroxylon peruiferum (used for medicinal and commercial purposes; Fabaceae). Crop species such as soybean (Glycine max; Fabaceae), coffee (Coffea arabica; Rubiaceae), tomato (Solanum esculentum; Solanaceae), eucalyptus (Eucalyptus grandis; Myrtaceae), olive (Olea europaea; Oleaceae), yam (Dioscorea alata; Dioscoreacea), and cassava (Manihot esculenta; Euphorbiaceae).

To test DNA quantity/quality, $1 \mu \mathrm{L}$ of each sample was run on $1 \%$ agarose gel with selected DNA Lambda of known concentration (L1 to L4 in Figure 1). DNA quality was also verified through EcoRI digestion for $3 \mathrm{~h}$ at $37^{\circ} \mathrm{C}$. We use DNA-HindIII as molecular weight standards for digestion agarose gel electrophoresis. A smear rather than a band is expected to be seen on the agarose gel if the DNA is correctly digested as the DNA is cleaved in fragments with a wide range of base-pair numbers. Since restriction endonucleases digest DNA at specific sequences, they can be used to cleave a DNA molecule at unique sites. For example, the restriction endonuclease EcoRI recognizes the six-base-pair sequence GAATTC. This sequence is present at five sites in DNA of the bacteriophage $\lambda$, so $E c o$ RI digests $\lambda$ DNA into six fragments ranging from 3.6 to 21.2 kilobases long ( 1 kilobase $=1000$ base pairs) (Cooper and Hausman, 2013).

To test the amplification by PCR, we used SSR primers developed to C. sylvestris (Cavallari et al, 2008) and A. humile (Grando C, Oliveira GCX, Bajay MM, Pinheiro JB, et al., unpublished results). For $C$. sylvestris, the reaction was performed in a $15 \mu \mathrm{L}$ mix containing $5.0 \mathrm{ng}$ template DNA, 1X PCR buffer, $3.0 \mathrm{mM} \mathrm{MgCl}, 0.2 \mathrm{mM}$ dNTP, $0.4 \mathrm{mg} / \mathrm{mL}$ BSA, 0.16 $\mu \mathrm{M}$ forward M13 5'-tail-end primer (CACGACGTTGTAAAACGAC), $0.2 \mu \mathrm{M}$ reverse primer, $0.30 \mu \mathrm{M}$ IRDye fluorescent-labelled M13 primer (700 or $800 \mathrm{nM}), 0.12 \mathrm{U} / \mu \mathrm{L}$ Taq polymerase (Invitrogen). A touchdown cycling program was inserted before normal cycling reaction, as follows: $5 \mathrm{~min}$ at $95^{\circ} \mathrm{C} ; 7$ cycles of $30 \mathrm{~s}$ at $94^{\circ} \mathrm{C}, 1 \mathrm{~min} 30 \mathrm{~s}$ of $67^{\circ} \mathrm{C}$ decreasing to $55^{\circ} \mathrm{C}$ at $2^{\circ} \mathrm{C}$ per cycle, $1 \mathrm{~min}$ at $72^{\circ} \mathrm{C}$ followed by 24 cycles of $30 \mathrm{~s}$ at $94^{\circ} \mathrm{C}, 1 \mathrm{~min} 30 \mathrm{~s}$ at $53^{\circ} \mathrm{C}, 1 \mathrm{~min}$ at $72^{\circ} \mathrm{C}$, and a final extension of $30 \mathrm{~min}$ at $60^{\circ} \mathrm{C}$. The reaction conditions and the amplification cycles were slightly different for $A$. humile. The PCR products were analyzed on 4200 DNA Analyser (Li-COR Biosciences) for C. sylvestris and on polyacrilamide gel 7\% (p/v) for A. humile.

\section{Equipment and solutions}

Pestle and mortars, autoclaved plastic-ware, a heat block or water bath $\left(65^{\circ} \mathrm{C}\right.$ and $\left.37^{\circ} \mathrm{C}\right)$, refrigerated centrifuge $\left(5900 \mathrm{~g}\right.$ at $\left.4^{\circ} \mathrm{C}\right)$ are required for this procedure. The method requires only 2 microtubes for each sample (there is only one transfer of supernatant). However, at the end of the procedure, some samples may present small fragments of tissue, which will require an additional centrifugation step for $1 \mathrm{~min}$ at $700 \mathrm{rpm}$ and transference of the supernatant to a new microtube.

The extraction buffer used in this procedure contained $100 \mathrm{mM}$ sodium acetate, 50 mM EDTA, pH 8.0, $500 \mathrm{mM} \mathrm{NaCl}, 4.6 \%$ soluble (w/v) PVP (MW 40,000, Sigma, St. Louis, MO, USA) adjusted to $\mathrm{pH} 5.5$. SDS was added to a final concentration of $1.4 \%(\mathrm{w} / \mathrm{v})$. Additional materials required included sodium bisulfite (MW 190.1, Sigma), 5 M potassium acetate, $\mathrm{pH}$ 5.2, Tris-EDTA, pH 8.0, containing $40 \mu \mathrm{g} / \mathrm{mL}$ RNase A (Sigma), 95\% ethanol, 70\% ethanol, and absolute isopropyl alcohol. 


\section{Protocol}

The protocol steps were conducted as follows:

1. Samples were ground using a mortar and pestle in liquid nitrogen and immediately stored $(100 \mathrm{mg})$ in plastic microtubes $(2 \mathrm{~mL})$ at $-80^{\circ} \mathrm{C}$ or in liquid nitrogen.

2. Immediately before starting the procedure, sodium bisulfite was added to the extraction buffer (final concentration of $1.65 \% \mathrm{w} / \mathrm{v}$ ) and the solution was mixed vigorously. Extraction buffer was preheated to $65^{\circ} \mathrm{C}$ in heat block or water bath.

3. To $100 \mathrm{mg}$ of ground material, $1 \mathrm{~mL}$ of extraction buffer was added.

4. The samples were incubated for $6-10 \mathrm{~min}$ at $65^{\circ} \mathrm{C}$ with occasionally swirling. The incubation time at $65^{\circ} \mathrm{C}$ can vary from 6 to $60 \mathrm{~min}$. Typically, 30-60 min is recommended for DNA isolation protocols. However, we observed that sample oxidation can occur during this step and that lowering the incubation time increases the DNA quality. No more than 6 min were needed to obtain satisfactory DNA yield $(\sim 50 \mathrm{ng} / \mu \mathrm{L})$ with minimum oxidation.

5. Samples were immediately cooled in an ice bath.

6. A total of $300 \mu \mathrm{L} 5 \mathrm{M}$ potassium acetate, $\mathrm{pH}$ 5.2, was added.

7. Samples were incubated on ice for $30 \mathrm{~min}$.

8. The samples were then centrifuged for $15 \mathrm{~min}$ at $5900 \mathrm{~g}$.

9. Supernatants were transferred to new microtubes. To $1 \mathrm{~mL}$ supernatant, $700 \mu \mathrm{L}$ cold isopropanol was added.

10. Samples were incubated for $30 \mathrm{~min}$ at $-20^{\circ} \mathrm{C}$.

11. Next, samples were centrifuged for $15 \mathrm{~min}$ at $5900 \mathrm{~g}$ at $4^{\circ} \mathrm{C}$.

12. The pellet was washed with $1 \mathrm{~mL}$ ethanol (70\%), followed by washing with $1 \mathrm{~mL}$ ethanol $(95 \%)$ and air drying of the pellet.

13. The pellet was resuspended in 50-100 $\mu \mathrm{L}$ TE containing $40 \mu \mathrm{g} / \mathrm{mL}$ RNAse; samples were incubated for $30 \mathrm{~min}$ at $37^{\circ} \mathrm{C}$.

\section{RESULTS AND DISCUSSION}

The DNA obtained using this method was high quality for all species tested, in contrast to Doyle and Doyle protocol (which used 1\% mercaptoethanol) and the other protocols, used that were inappropriate for a few species. DNA quantity using our extraction for most

species tested was approximately $50 \mathrm{ng} / \mu \mathrm{L}$ (Figure 1), and was compared with a standard of known concentration on an agarose gel. We expected DNA yield to be in the range of 20-100 $\mathrm{ng} / \mu \mathrm{L}$, which was observed following the use of our procedure.

DNA quality was sufficiently high to result in successful restriction digestion with endonucleases. Digestion of DNA from 6 species using EcoRI (Figure 2) showed high-quality results for the mercaptoethanol-, chloroform-, and phenol-free protocol with the expected smeared DNA pattern, while samples extracted by the Doyle and Doyle method produced unsatisfactory results, with samples remaining undigested by the enzyme EcoRI. The $\lambda$ DNAHindIII yields 8 fragments suitable, and both methodologies show fragment sizes with more than $9416 \mathrm{bp}$, even though Figure 2A shows fragments more separately than Figure 2B. Our suggested protocol worked well for all species tested and showed lower toxicity.

The protocol enables its use for the amplification of specific microsatellite loci. We used our protocol to extract DNA from 376 samples of C. sylvestris (Cavallari et al., 2010), which were successfully amplified using the 10 specific SSR markers as described by Cavallari et al. (2008), which 
had been used in a population genetic study (Figure 3A). The amplifications with 11 SSR markers developed for A. humile (Grando C, Oliveira GCX, Bajay MM, Pinheiro JB, et al., unpublished results) were successfully performed with 40 DNA samples extracted with our protocol (Figure 3B).

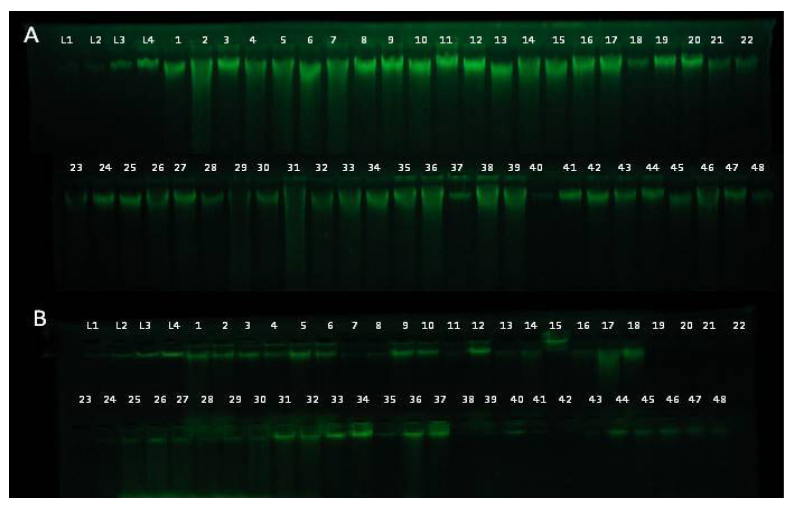

Figure 1. Electrophoresis of genomic DNA extracted from some of the species tested on 1\% agarose gel using the current protocol. The present protocol (A) was compared with the Doyle and Doyle protocol (B). Lanes 1-48 $=2$ $\mu \mathrm{L}$ genomic DNA (1-6 = Anacardium humile; 7-12 = Casearia sylvestris; 13-18 = Piptadenia gonoacantha; 19-24 = Vellozia squamata $; 25-30=$ Myroxylon peruiferum; 31-36= Manihot esculenta; $37-42=$ Dioscorea alata $; 43-48=$ Lippia alba) compared with lambda DNA ladder (L1 $=25 \mathrm{ng} / \mu \mathrm{L} ; \mathrm{L} 2=50 \mathrm{ng} / \mu \mathrm{L} ; \mathrm{L} 3=100 \mathrm{ng} / \mu \mathrm{L} ; \mathrm{L} 4=200 \mathrm{ng} / \mu \mathrm{L})$.

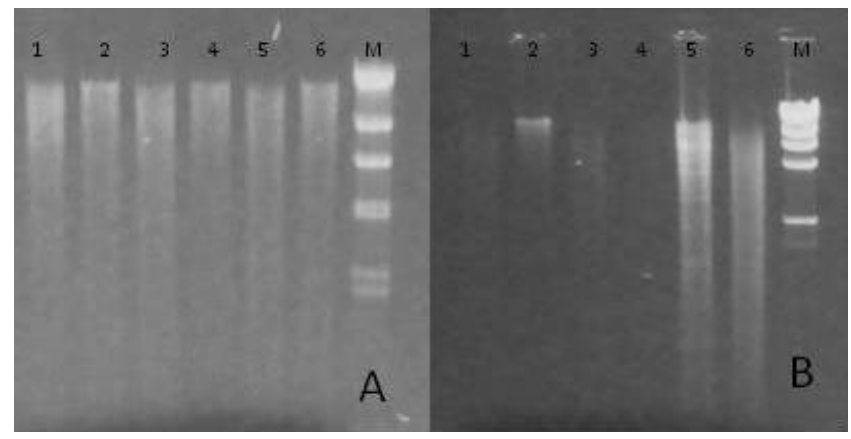

Figure 2. Ethidium bromide agarose DNA gel of electrophoretically separated restricted (EcoRI) genomic DNA. A. Digestion product from current protocol for DNA. B. Digestion product from the Doyle and Doyle protocol with modifications. Extraction lane $M=\lambda$ DNA-HindIII, lanes 1-6: restriction of DNA from Glycine max, Dioscorea alata, Casearia sylvestris, Lippia alba, Manihot esculenta, and Piptadenia gonoacantha, respectively.

A

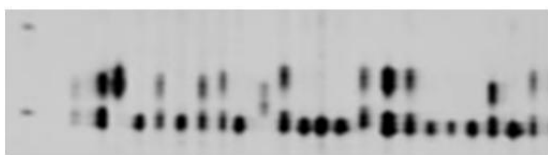

B

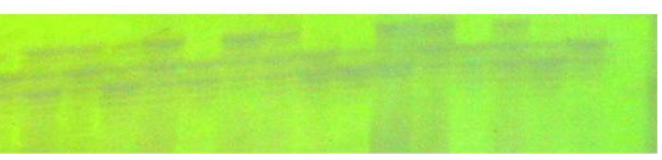

Figure 3. Gels of PCR amplification from microsatellite loci performed with DNA template obtained by the current protocol: A. amplification of the microsatellite locus Csy 04 for Casearia sylvestris on polyacrilamide gel of 4200 DNA Analyser (Li-COR Biosciences); B. amplification of the microsatellite locus Ahu 02 for Anacardium humile on polyacrilamide gel $7 \%(\mathrm{p} / \mathrm{v})$. 
Thus, our protocol provide DNA with significant high quality and quantity from most plant species, particularly wild tropical trees and shows some advantages related to the other ones. This protocol is considerably faster, because two people can process 150 samples or more in a single day using a centrifuge with a 24-microtube capacity ( 1.5 or $2 \mathrm{~mL}$ tubes). Another advantage of this method is that volatile reagents, such as mercaptoethanol, chloroform and phenol, are not necessary, showing low toxicity. All these advantages, together with the use of DNA in successful digestions and PCR amplifications with molecular markers, make this protocol very suitable to DNA extraction of plant species with high contents of secondary metabolites.

\section{ACKNOWLEDGMENTS}

Research supported by CNPq and FAPESP, Brazil. We thank Kaiser Schwarcz, Miklos Bajay, Márcia Duarte, and Nancy Farfan (Genetics Department, ESALQ/USP) for providing samples used in this study as well as to Thais Tomé for laboratory technical support.

\section{REFERENCES}

Aljanabi SM, Forget L and Dookun A (1999). An improved and rapid protocol for the isolation of polysaccharide- and polyphenol-free sugarcane DNA. Plant Mol. Biol. Rep. 17: 281.

Cavallari MM, Billot C, Bouvet JM, Favreau B, et al. (2008). Isolation and characterization of microsatellite markers for Casearia sylvestris Sw. (Salicaceae), a neotropical medicinal tree. Mol. Ecol. Resour. 8: 802-804.

Cavallari MM, Gimenes MA, Billot C, Torres RB, et al. (2010). Population genetic relationships between Casearia sylvestris (Salicaceae) varieties occurring sympatrically and allopatrically in different ecosystems in south-east Brazil. Ann. Bot. 106: 627-636.

Chaudhry B, Yasmeen A, Husnain T and Riazuddin S (1999). Mini-scale genomic DNA extraction from cotton. Plant Mol. Biol. Rep 17: 1-7.

Cooper GM and Hausman RE (2013). The Cell: A Molecular Approach. 5th edn. University of Boston, Boston.

Csaikl UM, Bastian H, Brettschneider R, Gauch S, et al. (1998). Comparative analysis of different DNA extraction protocols: a fast, universal maxi-preparation of high quality plant DNA for genetic evaluation and phylogentic studies. Plant Mol. Biol. Rep. 16: 69-86.

Doyle JJ and Doyle JL (1990). Isolation of plant DNA from fresh tissue. Focus 12: 13-15.

Li YX, Su ZX and Chen F (2002). Rapid extraction of genomic DNA from leaves and bracts of dove tree (Davidia involucrata). Plant Mol. Biol. Rep. 20: 185.

Narayanan C, Dubey S, Wali SA, Shukla N, et al. (2006). Optimization of DNA extraction for ISSR studies in Tectona grandis L.f. - an important forest tree species. Afr. J. Biotechnol 5: 1220-1223.

Sertie JA, Carvalho JC and Panizza S (2000). Antiulcer activity of the crude extract from the leaves of Casearia sylvestris. Pharm. Biol. 38: 112-119.

Shepherd M, Cross M, Stokoe RL, Scott LJ, et al. (2002). High-throughput DNA extraction from forest trees. Plant Mol. Biol. Rep. 20: 425.

Silva MAS, Ming LC, Pereira AMS, Bertoni BW, et al. (2006). Phytochemical and genetic variability of Casearia sylvestris Sw. from São Paulo State Atlantic Forest and Cerrado populations. Rev. Bras. Plantas Med. 8: 159-166.

Ziegenhagen B, Guillemaut P and Scholz F (1993). A procedure for mini-preparations of genomic DNA from needles of silver fir (Abies alba Mill.). Plant Mol. Biol. Rep. 11: 117-121. 